\title{
Gender Construction And Media Narratives: Representations Of Gender In Animated Movies
}

\author{
Sumera Batool \\ Department of Mass Communication \\ Lahore College for Women University \\ Maria Naeem \\ Department of Media \& Communication Studies, School of Social Sciences \& Humanities \\ University of Management and Technology \\ Feroza Batool \\ Department of Gender Studies \\ University of the Punjab
}

\begin{abstract}
Media, as an important and powerful social institution, contributes in the construction and reinforcement of perceptions and beliefs about gender. The media images of gender have been found stereotypical and discriminated while there have been many debates on the under representation and biased treatment of gender related issues. This research study particularly analyzed how media narratives play a part in the construction of gender identities in animated movies. The study focused to investigate how femininity and masculinity have been build up in movies, which sort of roles have been assigned to both genders and which identities have been emphasized in the animated movies of Time Warner and Walt Disney during the time period of 2008 to 2013. Gender schema and social learning theories gave implications to the research findings. Both quantitative and qualitative content analysis of fourteen animated movies was conducted. The study concluded that there is stereotypical representations of gender in movies. The women are under-represented and usually negatively portrayed while the men have shown with more societal powers.
\end{abstract}

Keywords: Gender Construction, Media Narratives and Animated Movies.

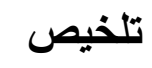

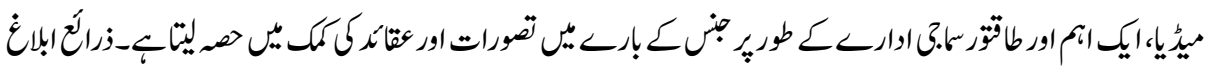

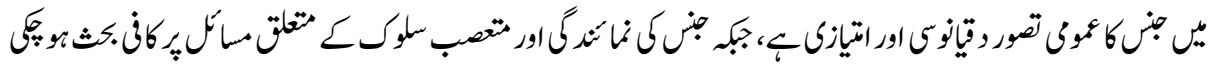

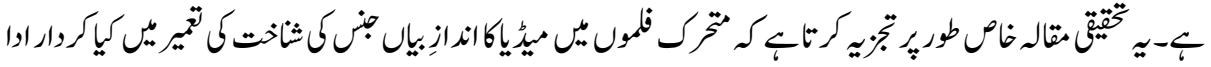

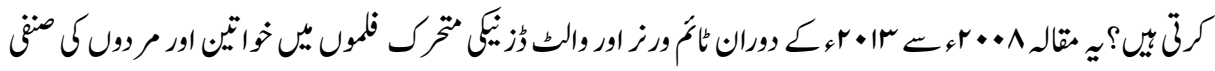

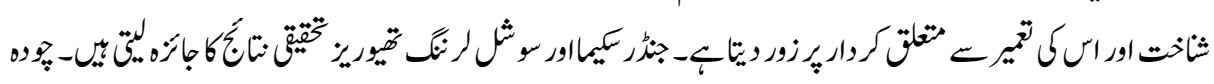




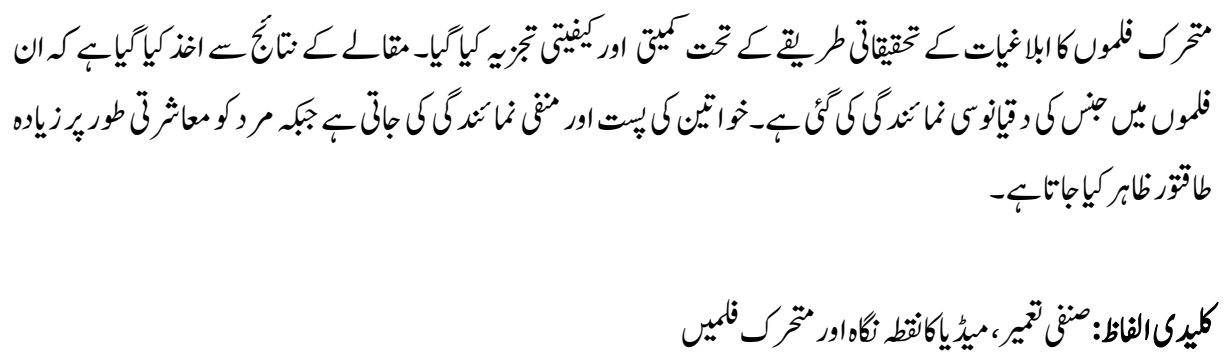

\section{Introduction}

Media is an important part of everyday lives of individuals, while for people just some options affects how they perceive themselves and the world around. It is interesting to see how the media portrays and depicts the gender. Since media is such a big part of people's everyday lives. The images of gender in media may consciously or unconsciously influence the individual's mind. It is very unlikely to think that the media is not there in the lives of people but their ways of thinking and the way they perceive the world and themselves is influenced by media (Gauntlett, 2008). Much academic attention has been given to the ideas of femininity and masculinity that they are culturally constructed and have naturally to do with ideology and power structures. The terms like sex, male and female, are based on cultural behavior expectation. Thus the assumption that how members of society see themselves, how they are viewed, and even treated, by others is determined to a great extent by their media representation. In this way media builds the perceptions about others and even maintains certain beliefs about others by representing them in a certain way. However, now a days, it is clear to most media researchers that these effects of media must be studied not assumed. With special concern to gender construction, there have been numerous research studies that highlight the repercussions of televised media. Traditional or customary ideas of gender construction or representation are correlated to higher and advanced levels of exposure to TV (Williams 1981; England, Descartes \& Collier-Meek 2011).

Beginning with early feminist writing, the media have been considered central social 'players' in this context. According to this argument, the media and the television in particular, present images of femininity (ies) and masculinity (ies) that do not simply reflect 'natural' sex differences, but actively participate in the symbolic discourse of gender, a discourse that is rooted in power relations. Importantly, mainly based on content analysis, these media representations- discussed particularly with regard to women- have been viewed as harmful images and as leading to sexist socialization, although some writers have cautioned of these effects being assumed rather than studied. 
In recent years, it has become clear that such an approach might ignore the full picture whereas masculinity (ies) should not be perceived as unproblematic. In patriarchal societies, the roles and privileges accorded to women are inferior to those assigned to men, such as sexism plays a central role in continuing oppression of women. (Swami et al., 2010).

This research attempts to highlight why it is important to understand how the media represent gender and argues that constructions of femininity and masculinity are part of a dominant ideology that prescribes 'proper' behavior for men and for women (Goffman, 1976).

\section{Literature Review}

Hermes (2007) explored that how both sexes are being represented in media with different patterns and there is a proportionate difference in representation of male and female. Researchers who have reported on this aspect (Belkaoui \& Belkaoui 1976; West 1984) explored that usually the images of women are stereotyped and portrayed as unemployed, have low income earnings and have limited purchasing power. Sometimes men are represented as criminal, clown, violent, child molesters and have lack of selfcontrol when related to anger or sexual urges and the stereotypes can be associated to male children acting brutally.

Leaper (2000) stated that the TV has been acknowledged as a dominant source of social inspiration and influence on children's gender perceptions. Furthermore, TV viewing has been associated with some pro-social besides belligerent behaviors (Calvert \& Huston 1987). Gender depiction in children's animated movies deserves much attention as the children start spending a lot of time on viewing animated movies and cartoons at a very early stage. As it has already argued, television content plays a major role in conveying the certain messages to children (Thompson \& Zerbinos 1995). Children are well aware of the gender cataloging in animated movies. The gender role depictions shown in animated movies may influence children's views, ideologies, beliefs, concepts and opinions about norms, relationships, social behaviors and gender (Oliver and Green 2001; Martin et al. 2002; Tonn 2008).

The literature argued for the powerful role of media and as a dominant source of social inspiration and influence on individual's gender perceptions. Furthermore, Traditional or customary ideas of gender construction or representation were found correlated to higher and advanced levels of exposure to media. The literature emphasized that both genders 
had been represented in media with different patterns and there was a proportionate difference in representation of males and females while usually the images of women have been stereotyped.

In the light of exiting body of literature the present study focuses on the representation and construction of gender in animated movies. The objectives of the study focus on:

- To explore whether men and women have been given equal representation in animated movies of selected time period

- To investigate which sort of roles have been assigned to both men and women.

- To analyze which identities have been emphasized for men and women in the animated movies of Time Warner and Walt Disney during the time period of 2008 to 2013.

\section{Theoretical Framework}

This study applies Gender Schema theory and Social Learning theory. Gender schema theory explained that how individuals become gendered in society and how sex-linked characteristics are maintained and transmitted to other members of a culture. Genderassociated information is predominantly transmitted through society by way of schemata, or networks of information that allow for some information to be more easily assimilated than others.

Social learning theory sheds light on this aspect that the behavior is almost learned by observing the environment. With the reference of this context, if the media performed their duty un-biased then media can be perfect teaching tool which have no competitor. Children observe the people around them behaving in various ways. In society children are surrounded by many influential models, such as parents within the family, characters on children's TV, friends within their peer group and teachers at school. These models provide examples of behaviour to observe and imitate, e.g. masculine and feminine, pro and anti-social etc. Most children are regularly exposed to animated cartoons (Klein et al. 2000).

Therefore this study argues that the more the children are exposed to stereotypical materials, the more chances they will learn and adopt the social practices about the gender behaviours from the animated cartoons on television, which they use to watch during most of the time of the day. Therefore in the presence of hegemonic control of 
state's patriarchal ideology and through stereotypical portrayal, the young boys are trained to learn to be more active, intelligent and aggressive while the young girls were encouraged to become attractive as well as passive. Therefore due to the existing values about gender which is disseminated through animated cartoons it is quite possible that in the process of socialization, all these kind of stereotypical representation of gender could be resulted in inferiority and superiority complex in girls and boys respectively.

Besides these theories, Feminist theorists also argued that how the system of power and oppression interact which contributed in gender differences, inequality and oppression which are also the theme of this research work. According to many feminist theorists focus on how women have been marginalized and defined as "others" in patriarchal societies, they also suggested that gender oppression goes beyond inequality by referring that not only women different from or unequal to men, but in fact they are actively oppressed subordinated and abused by men. The basic focus points of feminist theorists are that gender stratification occurs when gender differences give more power and privilege to men and the patriarchy society organizes the society into complex relationship. Many people incorrectly believe that feminist theory focuses exclusively on girls and women and that it has an inherent goal of promoting the superiority of women over men. In reality, feminist theory has always been about viewing the social world in a way that illuminates the forces that create and support inequality, oppression, and injustice, and in doing so, promotes the pursuit of equality and justice.

\section{Research Design}

The methodology opted for this study is content analysis. Content analysis is a method for summarizing any form of content by counting its various aspects. The animated movies of Time Warner and Walt Disney from 2009 to 2013 are universe of study. Fourteen movies of Time Warner and Walt Disney from 2009 to 2013 which are named as frozen, brave, princess and the frog, tangled, Wall-E, Toy story 3, cars 2, Wonder Women, all Stars are Superman, Arjun: The warrior prince, Mars Needs moms, Winnie the Pooh, Up and The monster University have been selected as sample by simple random method. Dialogues, characters, nature of representation and theme were units of analysis. Dialogues were categorized as supportive, against, neutral while characters 
were categorized as major, minor, background. The nature of representation and theme were analyzed as positive, negative and neutral.

\section{Operationalization of the Terms}

The theme and nature of representation in movies that established both gender as equal were considered as positive. The theme and nature of representation in movies that highlighted one gender over the other and established one gender as more powerful and dominant were operationalized as negative. The theme and nature of representation in which both genders were represented in un-biased manner and no such discrimination was highlighted between both genders has been termed as neutral. The dialogues which argued in the favour of basic rights of both genders were considered as supportive. The dialogues which portrayed one gender as dominant or oppressed and dependent were operationalized as against to any gender. The dialogues which were not suggestive in terms of favouring or opposing any gender considered as neutral.

The character around which the whole story of the movie revolves and all characters were linked to that lead or primary character was operationalized as major.

The characters which were acting as secondary and were indirectly linked to the main story of the movies were considered as minor characters. The characters which do not had any link with the theme of story or whose presence or absence were not affective to the plot of the movie were called background characters.

\section{Research Questions}

1. Whether the women have been given equal representation as compared to men?

2. What identities have been represented in animated movies for men and women?

3. How media narratives play a part in the construction of gender identities in animated movies?

4. How femininity and masculinity have been built up in animated movies? 


\section{Quantitative Findings}
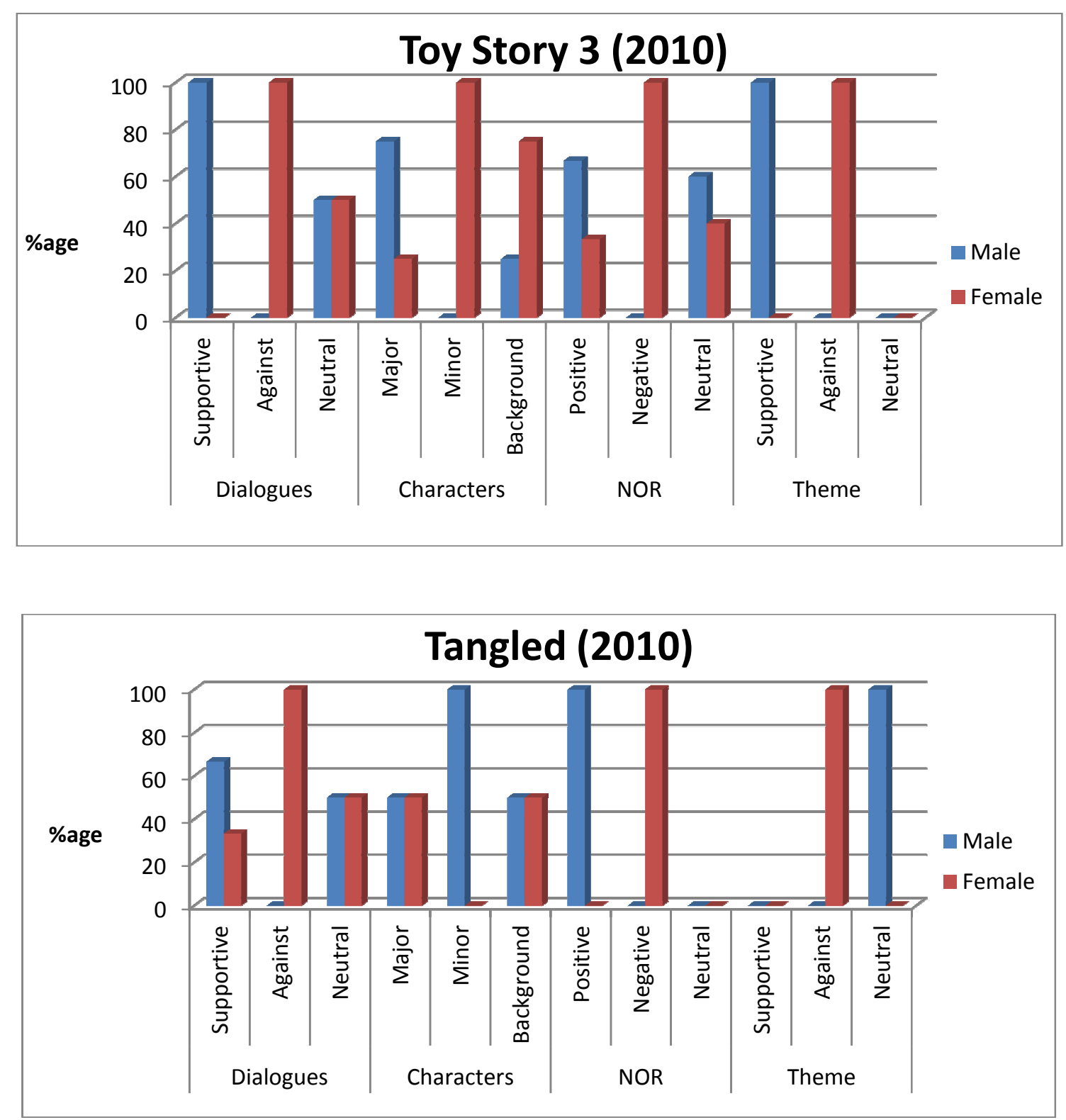

H1: Women are negatively represented in these movies as compared to men. 
Table: 1

Relationship between negative representation of women as compare to men

\begin{tabular}{|l|c|c|c|}
\hline & Value & DF & A symp. \\
\hline Pearson Chi-Square & $268.037^{\mathrm{a}}$ & 56 & .000 \\
\hline Likelihood Ratio & 237.143 & 56 & .000 \\
\hline Linear-by-Linear Association & 8.470 & 1 & .000 \\
\hline N of Valid Cases & 414 & & \\
\hline
\end{tabular}

The above table demonstrated that the value of "P" is less than the level of significance which is 0.05 . The outcomes verify that $\mathrm{H} 1$ is accepted.

H2: Women are under-represented in these movies as compared to men.

Table: 2

Relationship between under representation of women as compared to men

\begin{tabular}{|l|l|l|l|}
\hline & Value & DF & Asymp. Sig. \\
\hline Pearson Chi-Square & $188.451^{\mathrm{a}}$ & 21 & .000 \\
\hline Likelihood Ratio & 183.217 & 21 & .000 \\
\hline Linear-by-Linear Association & 67.566 & 1 & .000 \\
\hline N of Valid Cases & 414 & & \\
\hline
\end{tabular}

The table 2 is supporting $\mathrm{H} 2$ as level of significance ' 0.05 ' is higher than $\mathrm{P}$ value.

H3: Masculinity is being associated with societal power in animated movies

Table: 3

Relationship how societal power associated with masculinity

\begin{tabular}{|l|l|l|l|}
\hline & Value & df & Asymp. Sig. \\
\hline Pearson Chi-Square & $385.665^{\mathrm{a}}$ & 91 & .000 \\
\hline Likelihood Ratio & 278.445 & 91 & .000 \\
\hline Linear-by-Linear Association & .237 & 1 & .000 \\
\hline N of Valid Cases & 414 & & \\
\hline
\end{tabular}

The table 3 revealed that level of significance ' 0.05 ' is greater than $P$ value which affirms that $\mathrm{H} 3$ is accepted.

\section{Qualitative Analysis}

Qualitative content analysis is the method for the subjective interpretation of the content of text through the systematic classification process of coding and identifying themes or 
patterns. The study employed the systematic qualitative analysis and interpreted the text under the developed themes.

The themes included are:

- Patriarchy

- Masculine and feminine attributes

- Commodification of women

\section{Patriarchy}

Patriarchy is characterized by current and historic unequal power relations between women and men whereby women are systematically oppressed. This takes place across almost every sphere of life but is particularly noticeable in women's under-representation in key state institutions, decision-making positions and employment and industry. Male violence against women is also a key feature of patriarchy. Women in minority groups face multiple oppressions in this society, as race, class and sexuality.

In the animated movies the men were shown as the rulers and the decision makers in every sphere of life. As in the 'toy story 3 'the theme of the story revolves around the concept of team work. The leader of the first team is "Cow boy" while the other male characters which were included in the group such as buzz also had the right to take decision. The leader of the other team was also male character named 'Bear'. The concept engendered through this theme was if there is any tricky or complicated situation, males were there to find the solution, while the female characters had to follow the decision. The female characters were depicted as incompetent to get a solution for a problem and just to obey the decisions taken by men.

In another movie 'Brave' female character named 'Princess Merida' who was also the lead character of the movie has been represented in the movie as a confident and a bold girl, who want to take decision of her life by her own without the interference of anyone even her family. Her interests included archery and horse riding, which were considered as men oriented and not suitable for women.

She faced social pressure to change her life style as being women she should be getting marry. But Merida chooses to defy. Her parents continue to insist her but she stick to her decision and want to find some other way on her own basis. That's why Merida was portrayed in this movie as a rebellion girl. The representation of Merida has been shown as a transformed women who ultimate obey the decision of her parents and to get marry to reveal that it the ultimate task of a women to make family and modesty to follow the set norms and traditions. This shows the stereotypical representation of women that in a way strengthens the stereotypical thinking patterns of society. 


\section{Masculine and Feminine Attributes}

Gender is our social and legal status as girls and boys, women and men. Gender attributes is how you feel and express your gender. There are some certain attributes which are attached to specific gender and are learnt from observation of the surrounding such as society especially media. The traits which usually relate to men are strong, courageous, goal oriented and independent while women are generally perceived as beauty conscious, dependent and a passive sexual commodity.

In the movie 'Frozen' when the princes Anna went to protect her sister princess Elsa and even 'Flynn' protect her in every difficult situation he rescue her life. By representing such images for women and constructing belief that woman always need men for protection and they are dependent on men for social security and sustainability. The movies also set the beliefs about women as conscious about appearance and beauty and such stereotypical images has been emphasized rather than appreciating their talent. The women were not seen as a normal human identity but as a sex symbol. As in the movie 'Brave' suitors are interested in the appearance and the physical beauty of Princess Merida. No one among them cares about the talent and the other qualities of princess because they are treating her like an award to win and their major goal is just to get the princess. Yet all the suitors are tested on the basis of their skills, as it is generally perceived that men should be skilful and tactful.

Same as the case in the movie "Arjun: the Warrior Prince" where the princess has been treated as a trophy and princess "Daruppadi" was given to Arjun as a reward for his successful completion of mission. The princess has been represented as to encourage or console to Arjun. This movie constructs the beliefs that being women they should be more conscious or concerned about their looks or physical appearance rather than other qualities because it is the only quality that is socially expected and demanded. If a woman has strong character and is talented but not good in appearance then these qualities are not considered worthy enough to be appreciated by the society.

\section{Commodification of Women}

Commodification of women refers to the way women ideas and icons are appropriated for commercial purposes, emptied of their political significance and offered back to the public in a commoditized form - usually in media. Almost in every selected movie, the women have been represented as commodity or a sex object, who had to appeal and satisfy their opposite sex or they can be treated like a reward for a male on their achievements. In return female got a reward of romance and love from the opposite sex. In many movies 'Arjun; The Warrior Prince', 'All Stars Superman', 'Princess and the Frog' the female characters has been shown as sex object. 


\section{Discussion and Analysis}

The study investigated how femininity and masculinity have been build up in movies, which sort of roles have been assigned to both genders and which identities have been emphasized in the animated movies of Time Warner and Walt Disney during the time period of 2008 to 2013. Gender schema and social learning theories gave implications to the research findings.

\section{Whether the women have been giving equal representation as compared to men?}

The data suggested that in the animated movies from 2009-2011, male major characters were $32.8 \%$, males minor characters were $41.09 \%$, and male background characters were $26.0 \%$. As the percentages of female major characters are 27.7, female minor characters were $33.3 \%$ and female background characters were $38.8 \%$. So, the males had been represented more frequently as compared to females which showed that male characters were having more visible role in movies and women characters were less representative. Such difference in representation also depicted gender roles segregation in society that women are not engaged in visible and leading roles. So media is also reinforcing stereotypical segregation of gender roles.

\section{What identities have been represented in movies for men and women and how media narratives play a part in the construction of gender identities in animated movies?}

The results argued that men have been attributed as determined, bold, courageous, carrier oriented, independent, strong and brave while the women as to perform just household duties, to look after the home, sexy in appearance, beauty and weight conscious, delicate, feeble and independent. The analysis suggested that only men have the leadership power, and the women have to depend on men for their every single task. The theory 'Gender Schema theory' explained that the sex linked characteristics are maintained and transmitted to the other members of culture with the help of schemata or the network of information. So, in that manner the trait that the men should be dominant to women have been transmitted to the viewers and the animated movies are playing a very important role in this respect. Such kind of gender roles' representation is also contributing to existing discriminatory and stereotypical roles for women. As in most of the societies, women are considered inferior to men and treated as they do not have the ability of leadership and contribute in decision making roles. In those movies women were showed as sex object and engaged in private sphere as compare to men who are showed as symbol of power and authority. 


\section{How femininity and masculinity have been built up in animated movies?}

The research findings argued that the movies construct such identities for women that depict them as dependent gender, sex objects by determining the specific tasks for them as domestic duties to perform and a source of pleasure for men, while men as powerful, independent and strong. As the 'social learning theory' described that Individuals learn the behavior through observation and when they are exposed to the movies they observe and ultimate learn the identities represented by movies. By these ways movies come to determine the specification for both genders. Femininity was linked with the attribution of beauty to create sex appeal for men and Masculinity was specified with bravery and power to win the hearts of women to rule them. Such kind of women representation reflected the normative role of women in society and strengthening the stereotypical image of women as being inferior to men.

\section{Conclusions}

The study concluded that the animated movies construct the images of men and women and are source of socialization of its viewers by representing and emphasizing certain specific gender related attributes. Movies narratives play an important part in the image building and beliefs about the gender and gender roles. The results argued for the unequal and stereotypical treatment of women and women related issues that constructed the images for women as to perform domestic duties, sex commodity, beauty and weight conscious, delicate, feeble and independent whereas the men have been attributed as determined, bold, courageous, carrier oriented, independent, strong and brave. The women have been under represented and men have been overrepresented in comparison to each other. Most of the movies represented women in stereotypical roles and showed her inferior to men. Movies also promoted public private dichotomy of roles among gender.

\section{References}

Belkaoui, A. \& Belkaoui, M.J. (1976). A Comparative analysis of the Roles Portrayed by Women In Print Advertisement: 1958, 1970, 1972. Retrieved May 8, 2016 from : file://D:/Journals/Women's\%20Studies/vol.\%2015/New\%20Folder/Formated/500 6407.pdf

Calvert, S. L., \& Huston, A. C. (1987). Television and children's gender schemata. In L. S. Liben \& M. L. Signorella (Eds.), Children's gender schemata (pp. 75-88). San Francisco: Jossey-Bass. 
England, D. E., Descartes, L., \& Collier-Meek, M. A. (2001). Gender Role Portrayal and the Disney Princess. Journal of Sex Roles, 64, 555-567. Retrieved from http://dx.doi.org/10.1007/s11199-011-9930-7

Gauntlett, D. (2008). Moving experiences: Understanding television's influences and effects. London: John Libbey.

Goffman, E. (1976). Gender Advertisement. Retrieved https://genderdisplays.wordpress.com/ theory/

Hermes, J. (2007). Media Representation of Social structure: Gender. Retrieved June 21, 2016, from: http:/www.sagepub.com/mcquail6/Online\%20readings/5a\%20 Hermes\%20-Devereux-Ch-08.pdf

Leaper, C. (2000). The Social Construction and Socialization of Gender During Development. In P. H. Miller \& E. Kofsky Scholnick (Eds.), Toward a Feminist Developmental Psychology (pp. 127- 152). Florence: Taylor \& Frances/Routledge.

Martin, C. L., Ruble, D. N. \& Szkrybalo, J. (2002). Cognitive Theories of Early Gender Development. Psychological Bulletin, 128, 903-933. doi:1.1037/00332909.128.6.903.

Oliver, M. B. \& Green, S. (2001). Development of Gender Differences in Children's Responses to Animated Entertainment. Sex Roles, vol.45, pp.67-88. doi:1.1023/A:1013012401836.

Swami et. al. (2010). The Attractive Female Body Weight and Female Body Dissatisfaction in 26 Countries Across 10 World Regions: Results of the International Body. Retrieved from http://www.william-mckibbin.com/swami-vmckibbin-w-f-et-al-2010-the-attractive-female-body-weight-and-female-bodydissatisfaction-in-26-countries-across-10-world-regions-results-of-theinternational-body-project/

Thompson, T. L., \& Zerbinos, E. (1995). Gender Roles in Animated Cartoons: Has the Picture Changed in 20 Years? Sex Roles, 32, 651-673. doi:1.1007/BF01544217.

Tonn, T. (2008). Disney's Influence on Females Perception of Gender and Love. Retrieved on May 21, 2014, from: http://www2.uwstout.edu/content/lib/thesis/ 2008/2008tonnt.pdf 
212 Gender Construction and Media Narratives: Representations of Gender in Animated Movies

West, P. (1984). How the Media Portray Men? Retrieved July 3, 2016 from: http://www.boyslearning.com.au/articles/men/How\%20the\%20Media\%20Portray $\% 20$ Men.pdf

Williams, T. M. (1981). How and What do Children Learn From Television? Human Communication Research, 7, 180-190. Retrieved from: http://dx.doi.org/10.1111/j.1468-2958.1981.tb00568.x

Dr. Sumera Batool is an Assistant Professor in the Department of Mass Communication, Lahore College for Women University, Lahore.

Maria Naeem is Lecturer in the Department of Media \& Communication Studies, School of Social Sciences \& Humanities, University of Management and Technology.

Feroza Batool is Ph.D Scholar in the Department of Gender Studies, University of the Punjab, Lahore. 